\title{
PERBANDINGAN BERAT KUDA-KUDA BAJA ATAP LIMAS MENGGUNAKAN APLIKASI SAP 2000 - 2 DIMENSI DENGAN 3 DIMENSI
}

\author{
Irika Widiasanti, Sittati Musalamah
}

\begin{abstract}
This paper presents the comparison results of the weight steel truss of pyramid roof model. 2D and 3D Program in SAP 2000 were utilized to obtain the axial forces of each bar in the steel truss of pyramid roof model.

Five truss models were designed. They have $12 \mathrm{~m}, 15 \mathrm{~m}, 18 \mathrm{~m}, 21 \mathrm{~m}$ and $24 m$ of length respectively. Each long span was analyzed on $X$ and $Y$ axis directions using SAP 2000 program, in order to obtain axial forces. In $2 D$ program, the main truss was acted on $X$ axis direction and loaded by half of truss that acted on $Y$ axis direction. In $3 D$ program, all long spans of truss models were evaluated in $X$ and $Y$ axis directions as well. Steel profile with double angles was selected to support the axial forces. Hence, the weight of the entire truss can be calculated.

It is shown that the weight resulted from 3D program obtain is lighter than the weight calculated by 2D program. However, further research with more detail assumption in design is needed $n$ order to apply the result for more application such as: comparison of construction cost under different profile, different model or design.
\end{abstract}

Keyword : steel truss

Ir. Irika Widiasnti, MT

Staff Pengajar Jurusan Teknik Sipil

Fakultas Teknik

Universitas Negeri Jakarta, 13220

email : irika@ymail.com

\author{
Sittati Musalamah, MT \\ Staff Pengajar Jurusan Teknik Sipil \\ Fakultas Teknik \\ Universitas Negeri Jakarta, 13220
}

\section{PENDAHULUAN}

Umumnya untuk rumah sederhana rangka penutup atap menggunakan bahan kayu baik berbentuk limas maupun bentuk lainnya. Penggunaan bahan kayu didasarkan atas pertimbangan biaya, akan tetapi dengan semakin sulitnya mendapatkan kayu yang berkualitas maka kecenderungan harga kayu semakin mahal. Fakta ini membuat kecenderungan sebagian perencana memilih menggunakan bahan alternatif material lain dengan tetap mempertimbangkan unsur ekonomis dan analisis Teknik. 
Terdapat alternatif yang bisa digunakan sebagai bahan pembuat kuda-kuda, yaitu dengan menggunakan beton dan baja. Tetapi terdapat perbedaan yang mencolok dari segi beratnya apabila kedua bahan ini diaplikasikan sebagai kuda-kuda. Kuda-kuda beton akan menghasilkan berat sendiri yang jauh lebih besar daripada kuda-kuda baja. Karena itulah penggunaan kuda-kuda baja akan lebih banyak memberikan keuntungan daripada beton ataupun kayu.

Penggunaan baja sebagai bahan pembuat kuda-kuda semakin dikenal luas akhir-akhir ini. Hal ini didukung oleh makin mudahnya didapat kuda-kuda ini di pasaran, karena telah diproduksi secara massal di Indonesia. Biasanya kuda-kuda baja ini ditawarkan dalam bentuk satu kesatuan dengan elemen atap lainnya, sehingga dikenal dengan sebutan rangka atap baja ringan.

Sesuai namanya, material untuk rangka ini terbuat dari bahan dasar baja dengan campuran zinc dan aluminium (zinc-alum). Rangka baja ini terdiri dari lempengan-lempengan (profil) yang bervariasi bentuk dan ukurannya, sesuai fungsi masing-masing dalam struktur rangka atap. Untuk kuda-kuda dan gording digunakan profil berbentuk "I" atau "U" terbalik dan memiliki ukuran yang lebih besar. Sedangkan untuk reng digunakan profil yang paling kecil bentuk dan ukurannya.

Dengan sistem pabrikasi (perakitan) yang efisien dan praktis, rangka atap baja ringan dapat memenuhi tuntutan akan efisiensi waktu dalam penyelesaian konstruksi. Yang dimaksud pabrikasi disini adalah suatu sistem perakitan bukan di lokasi/titik terpasang perangkat terkait, sehingga memungkinkan akurasi yang tepat dengan berbagai ukuran yang ada pada gambar kerja.

Rangka atap baja ringan diset sesuai spesifikasi yang tertuang dalam gambar detail mengikuti bentuk dan ukuran yang terinci. Dalam bentuk yang hampir atau telah utuh setelah diikat dan disatukan oleh jepitan sekrup atau sejenisnya, material rangka atap dinaikkan pada posisinya di atas pasangan dinding bata atau balok beton. Setelah berada pada dudukan yang tepat, lau dilakukan pengikatan mengikuti prosedur teknis selanjutnya. Namun, sistem pabrikasi yang efisien dan praktis ini juga mempunyai beberapa kelemahan. Diantaranya adalah tidak adanya presisi pada garis level pasangan dinding bata atau balok beton yang menjadi tempat dudukan kuda-kuda baja ringan tersebut. Dengan demikian diperlukan revisi berupa penambalan, pengganjalan ataupun pembobolan dan pemangkasan di bagian-bagian yang tidak sama ketinggiannya

Masalah yang lain adalah terjadinya pemuntiran pada bagian rangka atau profil baja tertentu akibat kecerobohan pemasangan. Selain itu bisa juga terjadi kelalaian dalam peletakan profil baja yang berfungsi sebagai reng., yang berakibat tidak rapinya pemasangan genteng pada tahap selanjutya. Kendala yang lain adalah dari segi biaya. Pemasangan rangka atap baja ringan ini juga masih lebih mahal daripada rangka atap kayu. Disamping itu pengerjaan rangka atap baja ringan ini juga 
memerlukan kecermatan tinggi. Pelaksanaan dengan intensitas tinggi (misalnya pada perumahan dengan jumlah unit yang sangat banyak) dan dituntut dead line waktu, dapat menimbulkan kesalahan. Karena itu diperlukan pengawasan yang ketat pada saat pemasangan rangka atap tersebut.

Ada beberapa hal yang perlu diperhatikan sebelum menggunakan rangka atap baja ringan ini. Yaitu penting untuk memilih material baja ringan yang kuat berdasarkan perhitungan sruktur bentuk profilnya. Sebaiknya dihindarkan jatuhnya adukan semen pada porfil saat melakukan plesteran dinding atau ketika pemasangan nok genteng. Adukan semen yang jatuh dapat mengganggu kerapian perangkat kuda-kuda. Dan karena adukan semen mempunyai daya lekat yang kuat maka dapat mengakibatkan kerusakan pada lapisan coating material baja tersebut. Lapisan atau coating ini berfungsi sebagai pelindung material baja dari proses korosi, sehingga kemampuannya dalam menahan korosi menjadi empat kali lipat dari baja biasa.

Melihat berbagai hal yang harus mendapat perhatian khusus pada penggunaan dari rangka atap baja ringan pabrikasi, maka rangka atap baja biasa tetap mendapat tempat di dunia konstruksi sesuai dengan kondisi yang dihadapi. Apalagi analisa perhitungan struktur kuda-kuda, berkembang sejalan dengan perkembangan teknologi. Karena proses analisa struktur secara manual seringkali menemui proses perhitungan berulang yang menghabiskan banyak waktu dan hasil yang didapat belum tentu akurat. Sementara penggunaan program-program komputer, terutama bidang analisa struktur memberi kemudahan dalam hal pengoperasiannya, akurasi hasil dan penghematan waktu.

Dikenal beberapa macam program perhitungan analisa struktur, antara lain: STAAD, ETABS, RISA, STRUDL, GRASP, MICROFEAP dan SAP. Dari sekian macam program tersebut, SAP (Structural Analysis Program) merupakan program yang lebih banyak dikenal yang dapat menganalisa berbagai kondisi struktur seperti frame (portal) ataupun truss (rangka) baik dengan analisa 2 dimensi (2D) ataupun 3 dimensi (3D)

Semua permasalahan yang telah diidentifikasikan di atas sangat penting untuk diteliti dan dikaji lebih mendalam. Mengingat keterbatasan waktu, tenaga dan biaya penelitian maka penelitian ini hanya menitikberatkan pada perhitungan kuda-kuda apabila ditinjau dari analisis ekonomi yang hanya mempertimbangkan dari sisi penggunaan bahan (berat konstruksi) dan tidak mempertimbangkan metode pelaksanaan. Analisis teknisnya hanya menggunakan SAP 2000 dengan tinjauan 2 dimensi dan 3 dimensi

Masalah dalam penelitian ini dapat dirumuskan sebagai berikut: bagaimana perbandingan hasil perhitungan kuda-kuda apabila dianalisa menggunakan SAP 2000 2D dan 3D ditinjau dari dari analisis ekonomis dengan tetap mempertimbangkan kekuatannya (analisis teknis). 


\section{METODA}

Metode yang digunakan adalah penelitian di laboratorium untuk memperoleh data, berlokasi di Jurusan Teknik Sipil Fakultas Teknik Universitas Negeri Jakarta. Teknik pengumpulan data dengan pengujian di laboratorium menggunakan SAP 2000 - 2 Dimensi (2D) dan 3 Dimensi (3D), menggunakan jenis sampel bertujuan (purposive), yaitu kuda-kuda atap limas dengan bentang 12, 15, 18, 21 dan 24 meter.

Penelitian dimulai dengan melakukan perhitungan perencananaan kuda-kuda rangka. Pada dasarnya langkah perhitungan yang umum digunakan untuk pendimensian kuda-kuda adalah dengan menggunakan teori Cremona sebagai metode analisa strukturnya, ataupun dengan menggunakan kesetimbangan gaya di titik buhul. Sebelum dianalisa dengan metode Cremona, harus sudah diketahui macam dan besar beban yang direncanakan akan didukung oleh kuda-kuda tersebut.

Beban yang diperhitungkan di sini adalah: berat sendiri, beban guna dan beban angin. Yang dimaksud berat sendiri adalah berat bahan penutup atap, berat gording, berat air hujan dan berat sendiri kuda-kuda. Dari beragam beban tersebut kemudian dilakukan kombinasi pembebanan. Dan kombinasi pembebanan yang terbesar digunakan sebagai beban pada proses analisa struktur. Hasil analisa struktur adalah berupa besar gaya di masing-masing batang kuda-kuda tersebut beserta sifat gayanya (tekan atau tarik). Berdasarkan besar dan sifat gaya tersebut kemudian direncanakan dimensi batang masing-masing bagian kuda-kuda.

Langkah berikutnya adalah perhitungan sambungan pada masing-masing titik buhul. dengan mengetahui besarnya gaya yang bekerja pada masing-masing batang yang bertemu di titik buhul yang ditinjau. Kemudian diitentukan jenis sambungan yang dipakai dan diikuti prosedur perhitungan sesuai jenis sambungan yang dipilih.

Langkah-langkah perhitungan secara manual seperti dijelaskan di atas, kemudian dapat lebih diringkas dengan menggunakan bantuan software program analisa struktur. Selain lebih menghemat waktu, penggunaan program tersebut juga memberikan hasil perhitungan yang lebih akurat dan mudah ditelusuri kesalahan-kesalahan asumsinya.

Secara skematis, tahapan penelitian yang akan dilakukan digambarkan pada Gambar 1 berikut. 


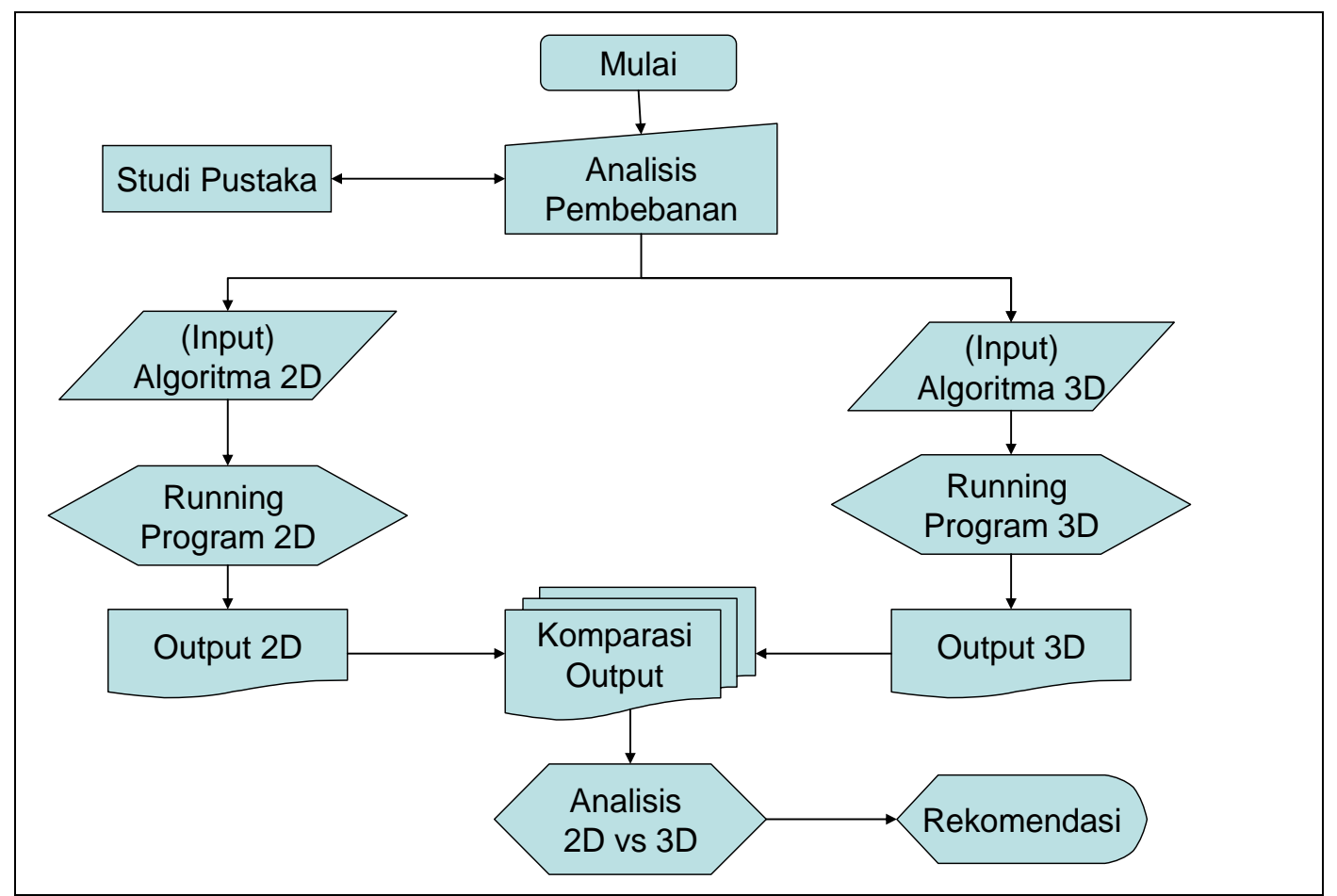

Gambar 1. Diagram Tahapan Penelitian

\section{HASIL DAN PEMBAHASAN}

\section{DESKRIPSI HASIL PENELITIAN}

Kuda-kuda yang dijadikan sampel penelitian yaitu kuda-kuda atap limas dengan bentang 12, 15, 18, 21 dan 24 meter dengan bentuk rangka kuda-kuda sebagai berikut :

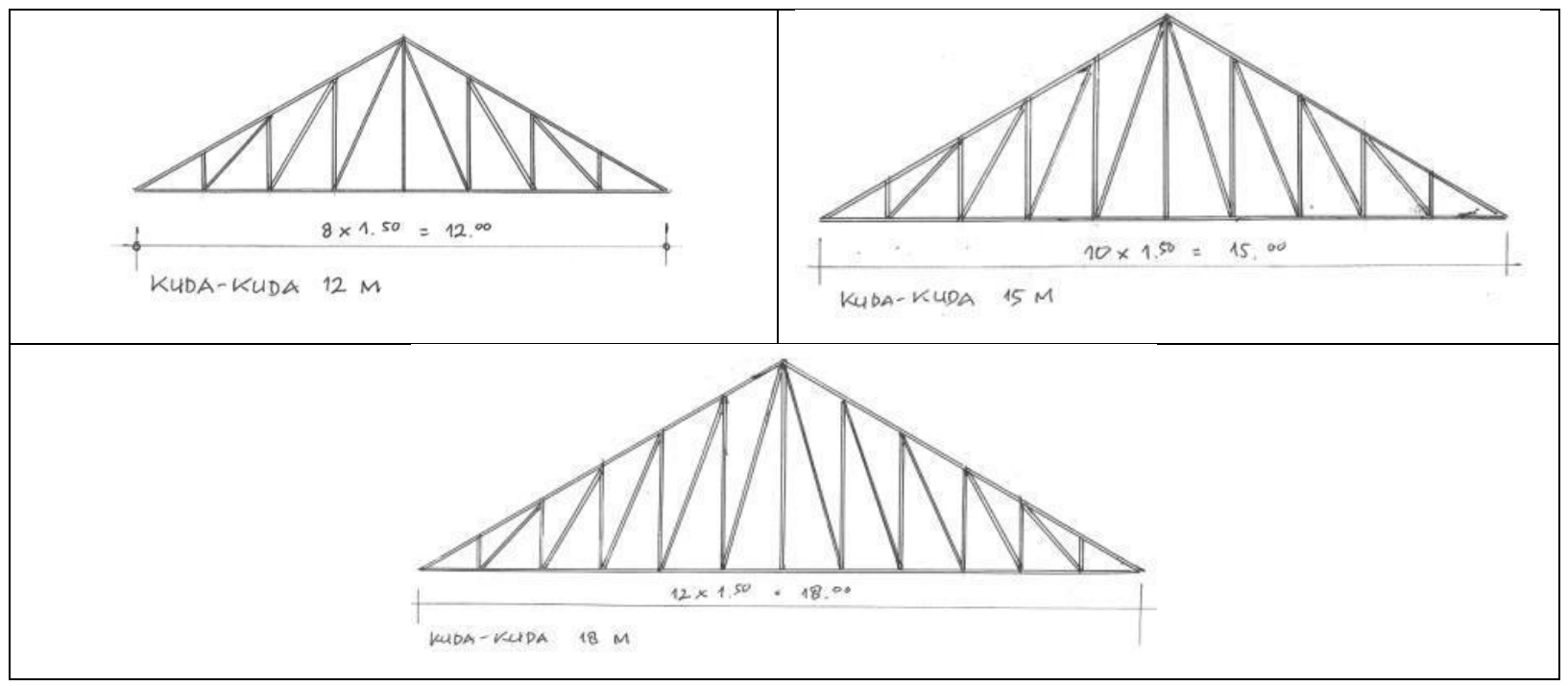

Gambar 2. Bentuk Kuda-kuda 
Beban kuda-kuda dihitungkan pada setengah bentang, dikarenakan bentuk kuda-kuda yang simetris. Pada perhitungan SAP 2 dimensi, kuda-kuda arah $Y$ menjadi kuda-kuda anak yang membebani kuda-kuda arah $X$ sebagai kuda-kuda utama. Sedangkan Pada perhitungan SAP 3 dimensi, kuda-kuda arah $X$ dan arah $Y$ dihitung bersama-sama sebagai penahan beban atap.

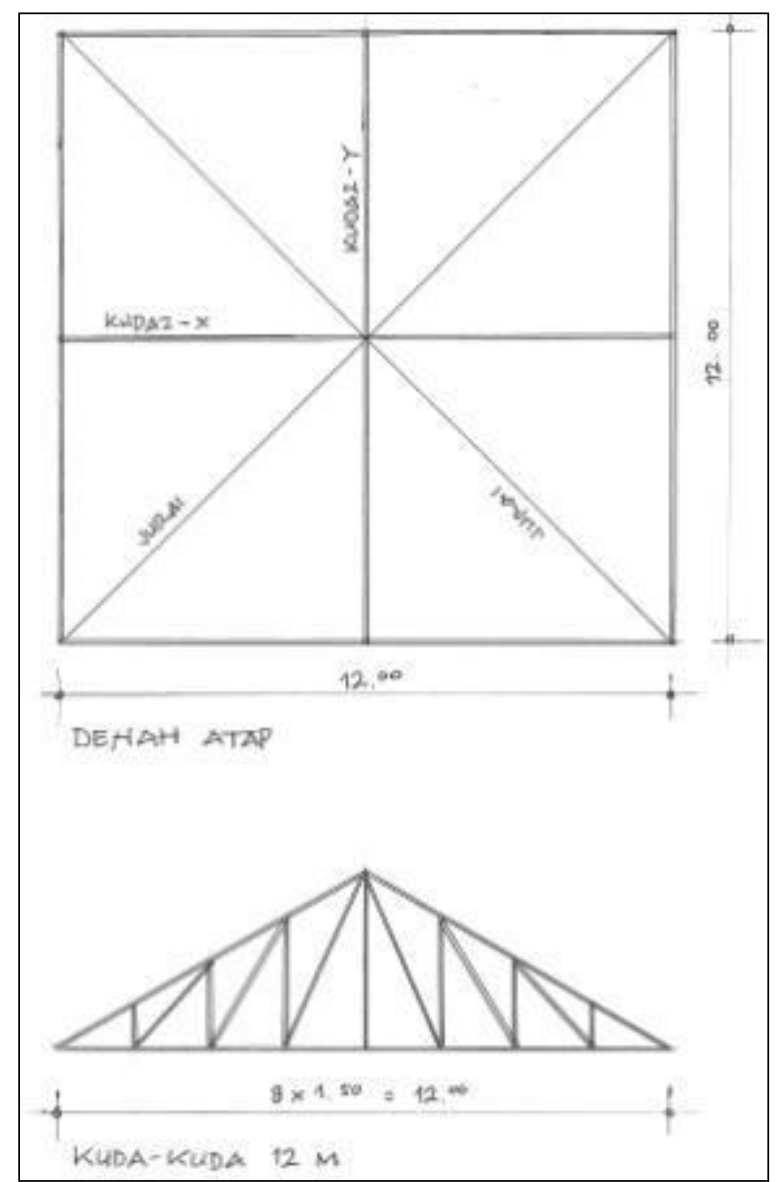

Gambar 3. Pembebanan Kuda-kuda

Beban kuda-kuda tiap titik simpul untuk tiap bentang adalah sebagaimana terlihat pada Gambar 4 dan Gambar 5 
ISSN: $1907-4360$

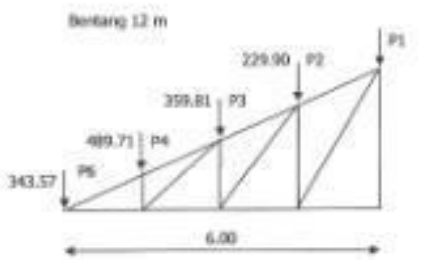

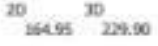

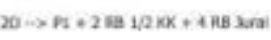

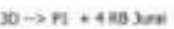

thatan za - setom tuda tude
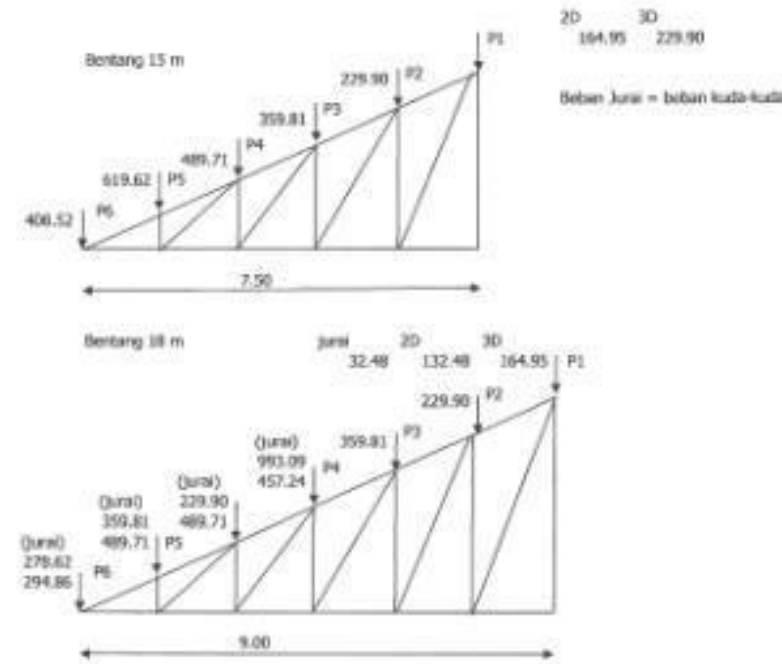

Gambar 4. Beban Kuda-kuda bentang 12 M, 15 M, 18 M

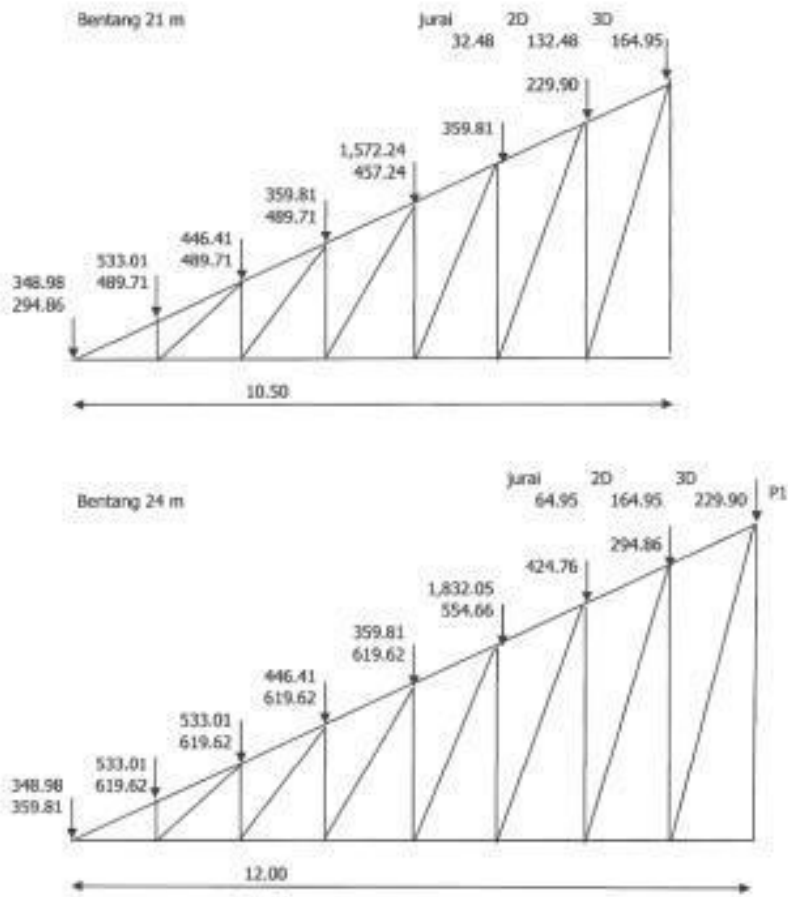

Gambar 5. Beban Kuda-kuda bentang 21 M, 24 M

Perbandingan Berat Kuda - Kuda Baja Atap Limas 2 Dimensi dengan 3 Dimensi 


\section{PEMBAHASAN HASIL PENELITIAN}

\section{Gaya Batang}

Berdasarkan perhitungan gaya batang menggunakan SAP, gaya batang pada kuda-kuda arah $\mathrm{X}$ yang dihitung dengan metode 2 dimensi menghasilkan gaya batang yang lebih besar daripada perhitungan 3 dimensi.

Tabel 1. Gaya Batang kuda-kuda bentang $18 \mathrm{M}$

\begin{tabular}{|c|c|c|c|c|c|c|c|c|c|}
\hline Frame & Station & $P=2 D$ & $P=3 D$ & selisih & Frame & $\begin{array}{l}\mathrm{P}-1 / 2 \\
\text { kuda2 }\end{array}$ & $\begin{array}{c}\text { selisih 2D- } \\
1 / 2\end{array}$ & $\begin{array}{c}\text { selisih 3D- } \\
1 / 2\end{array}$ & \\
\hline Text & $\mathrm{m}$ & Kgf & Kgf & Kgf & Text & Kgf & Kgf & Kgf & \\
\hline 1 & 1.5 & 9222.04 & 5481.56 & $3,740.48$ & 1 & $1,017.00$ & $8,205.04$ & $4,464.56$ & bawah \\
\hline 2 & 1.5 & 8797.92 & 5057.45 & $3,740.47$ & 2 & 592.89 & $8,205.03$ & $4,464.56$ & bawah \\
\hline 3 & 1.5 & 8373.81 & 4633.34 & $3,740.47$ & 3 & 168.78 & $8,205.03$ & $4,464.56$ & bawah \\
\hline 4 & 1.5 & 7963.76 & 4223.28 & $3,740.48$ & 4 & -241.28 & $8,205.04$ & $4,464.56$ & bawah \\
\hline 5 & 1.5 & 7593.08 & 3852.61 & $3,740.47$ & 5 & -611.95 & $8,205.03$ & $4,464.56$ & bawah \\
\hline 6 & 1.5 & 7279.59 & 3539.12 & $3,740.47$ & 6 & -925.44 & $8,205.03$ & $4,464.56$ & bawah \\
\hline 7 & 1.5 & 7279.59 & 3539.12 & $3,740.47$ & & & & & bawah \\
\hline 8 & 1.5 & 7593.08 & 3852.61 & $3,740.47$ & & & & & bawah \\
\hline 9 & 1.5 & 7963.76 & 4223.28 & $3,740.48$ & & & & & bawah \\
\hline 10 & 1.5 & 8373.81 & 4633.34 & $3,740.47$ & & & & & bawah \\
\hline 11 & 1.5 & 8797.92 & 5057.45 & $3,740.47$ & & & & & bawah \\
\hline 12 & 1.5 & 9222.04 & 5481.56 & $3,740.48$ & & & & & bawah \\
\hline 13 & 0.866 & -489.71 & -489.71 & 0.00 & 7 & -489.71 & 0.00 & 0.00 & tegak \\
\hline 14 & 1.732 & -734.57 & -734.57 & 0.00 & 8 & -734.57 & 0.00 & 0.00 & tegak \\
\hline 15 & 2.598 & -946.95 & -946.95 & 0.00 & 9 & -946.95 & 0.00 & 0.00 & tegak \\
\hline 16 & 3.464 & -1070.02 & -1070.02 & 0.00 & 10 & $-1,070.02$ & 0.00 & 0.00 & tegak \\
\hline 17 & 4.33 & -1085.92 & -1085.92 & 0.00 & 11 & $-1,085.92$ & 0.00 & 0.00 & tegak \\
\hline 18 & 5.196 & 0 & 0 & 0.00 & 12 & $-1,069.88$ & $1,069.88$ & $1,069.88$ & tegak \\
\hline 19 & 4.33 & -1085.92 & -1085.92 & 0.00 & & & $-1,085.92$ & & tegak \\
\hline 20 & 3.464 & -1070.02 & -1070.02 & 0.00 & & & $-1,070.02$ & & tegak \\
\hline 21 & 2.598 & -946.95 & -946.95 & 0.00 & & & -946.95 & & tegak \\
\hline 22 & 1.732 & -734.56 & -734.57 & 0.01 & & & -734.56 & & tegak \\
\hline 23 & 0.866 & -489.71 & -489.71 & 0.00 & & & -489.71 & & tegak \\
\hline 24 & 1.73204 & -10648.61 & -6329.52 & $-4,319.09$ & 13 & $-2,242.93$ & $-8,405.68$ & $-4,086.59$ & atas \\
\hline 25 & 1.73204 & -10648.61 & -6329.52 & $-4,319.09$ & 14 & $-2,242.93$ & $-8,405.68$ & $-4,086.59$ & atas \\
\hline 26 & 1.73204 & -10158.89 & -5839.8 & $-4,319.09$ & 15 & $-1,753.21$ & $-8,405.68$ & $-4,086.59$ & atas \\
\hline
\end{tabular}




\begin{tabular}{|c|c|c|c|c|c|c|c|c|c|}
\hline Frame & Station & $P=2 D$ & $P=3 D$ & selisih & Frame & $\begin{array}{l}\mathrm{P}-1 / 2 \\
\text { kuda2 }\end{array}$ & $\begin{array}{c}\text { selisih 2D- } \\
1 / 2\end{array}$ & $\begin{array}{c}\text { selisih 3D- } \\
1 / 2\end{array}$ & \\
\hline Text & $\mathrm{m}$ & Kgf & Kgf & Kgf & Text & Kgf & Kgf & & \\
\hline 27 & 1.73204 & -9669.17 & -5350.08 & $-4,319.09$ & 16 & $\begin{array}{l}-1,263.48 \\
\end{array}$ & $-8,405.69$ & $-4,086.60$ & atas \\
\hline 28 & 1.73204 & -9195.69 & -4876.59 & $-4,319.10$ & 17 & -790.00 & $-8,405.69$ & $-4,086.59$ & atas \\
\hline 29 & 1.73204 & -8767.67 & -4448.57 & $-4,319.10$ & 18 & -361.98 & $-8,405.69$ & $-4,086.59$ & atas \\
\hline 30 & 1.73204 & -8767.67 & -4448.57 & $-4,319.10$ & & & $-8,767.67$ & & atas \\
\hline 31 & 1.73204 & -9195.69 & -4876.59 & $-4,319.10$ & & & $-9,195.69$ & & atas \\
\hline 32 & 1.73204 & -9669.17 & -5350.08 & $-4,319.09$ & & & $-9,669.17$ & & atas \\
\hline 33 & 1.73204 & -10158.89 & -5839.8 & $-4,319.09$ & & & $-10,158.89$ & & atas \\
\hline 34 & 1.73204 & -10648.61 & -6329.52 & $-4,319.09$ & & & $-10,648.61$ & & atas \\
\hline 35 & 1.73204 & -10648.61 & -6329.52 & $-4,319.09$ & & & $-10,648.61$ & & atas \\
\hline 36 & 2.29125 & 647.83 & 647.83 & 0.00 & 19 & 647.83 & 0.00 & 0.00 & diagonal \\
\hline 37 & 2.99993 & 848.21 & 848.21 & 0.00 & 20 & 848.21 & 0.00 & 0.00 & diagonal \\
\hline 38 & 3.77482 & 1031.92 & 1031.92 & 0.00 & 21 & $1,031.92$ & 0.00 & 0.00 & $\begin{array}{l}\text { diagonal } \\
\end{array}$ \\
\hline 39 & 4.58246 & 1132.41 & 1132.41 & 0.00 & 22 & $1,132.41$ & 0.00 & 0.00 & diagonal \\
\hline 40 & 5.40818 & 1130.26 & 1130.26 & 0.00 & 23 & $1,130.26$ & 0.00 & 0.00 & diagonal \\
\hline 41 & 5.40818 & 1130.26 & 1130.26 & 0.00 & & & & & diagonal \\
\hline 42 & 4.58246 & 1132.41 & 1132.41 & 0.00 & & & & & diagonal \\
\hline 43 & 3.77482 & 1031.92 & 1031.92 & 0.00 & & & & & diagonal \\
\hline 44 & 2.99993 & 848.21 & 848.21 & 0.00 & & & & & diagonal \\
\hline 45 & 2.29125 & 647.83 & 647.83 & 0.00 & & & & & $\begin{array}{l}\text { diagonal } \\
\end{array}$ \\
\hline
\end{tabular}

Dari tabel di atas, terlihat bahwa, perbedaan gaya batang terjadi pada batang atas dan batang bawah, sedangkan untuk batang vertikal dan diagonal hasilnya sama untuk perhitungan 2 dimensi (kudakuda utuh dan setengah kuda-kuda) maupun perhitungan 3 dimensi.

\section{(a) Dimensi Batang}

Perhitungan dimensi batang didasarkan pada gaya batang maksimum yang terjadi untuk setiap jenis batang. Sebagai contoh pada batang bawah yang merupakan batang tarik, diambil gaya batang terbesar untuk pendimensian semua batang bawah. Pada penelitian ini konstruksi kuda-kuda menggunakan profil double siku sama kaki dengan pelat buhul tebal $10 \mathrm{~mm}$.

\section{(b) Berat kuda-kuda}

Berdasarkan profil yang didapat untuk setiap jenis batang, maka didapat berat profil penyusun konstruksi rangka kuda-kuda. Sebagai pendekatan untuk menghitung berat alat penyambung, diambil $10 \%$ dari berat konstruksi kuda-kuda. 
Tabel 2. Berat konstruksi Kuda-kuda KK1 bentang $15 \mathrm{M}-2$ dimensi

\begin{tabular}{|c|c|c|c|c|c|c|c|}
\hline Bentang & Frame & Station & $P$ & & Profil & berat & berat \\
\hline $\mathrm{m}$ & Text & $M$ & Kgf & & & $\mathrm{kg} / \mathrm{m}$ & $\mathrm{kg}$ \\
\hline $15-2 D$ & 1 & 1.5 & 7682.23 & bawah & \lrcorner L 45.45 .5 & 3.38 & 5.070 \\
\hline $15-2 D$ & 2 & 1.5 & 7145.61 & bawah & \lrcorner $\mathrm{L} 45.45 .5$ & 3.38 & 5.070 \\
\hline $15-2 D$ & 3 & 1.5 & 6683.99 & bawah & $J \mathrm{~L} 45.45 .5$ & 3.38 & 5.070 \\
\hline $15-2 D$ & 4 & 1.5 & 6297.38 & bawah & \lrcorner$\llcorner 45.45 .5$ & 3.38 & 5.070 \\
\hline $15-2 D$ & 5 & 1.5 & 5985.76 & bawah & \lrcorner$\llcorner 45.45 .5$ & 3.38 & 5.070 \\
\hline $15-2 D$ & 6 & 1.5 & 5985.76 & bawah & \lrcorner $L 45.45 .5$ & 3.38 & 5.070 \\
\hline $15-2 D$ & 7 & 1.5 & 6297.38 & bawah & \lrcorner$\llcorner 45.45 .5$ & 3.38 & 5.070 \\
\hline $15-2 D$ & 8 & 1.5 & 6683.99 & bawah & \lrcorner$\llcorner 45.45 .5$ & 3.38 & 5.070 \\
\hline $15-2 D$ & 9 & 1.5 & 7145.61 & bawah & \lrcorner$\llcorner 45.45 .5$ & 3.38 & 5.070 \\
\hline $15-2 D$ & 10 & 1.5 & 7682.23 & bawah & \lrcorner$\llcorner 45.45 .5$ & 3.38 & 5.070 \\
\hline $15-2 D$ & 11 & 0.866 & -619.62 & tegak & \lrcorner $L 30.30 .3$ & 1.36 & 1.178 \\
\hline $15-2 D$ & 12 & 1.732 & -799.52 & tegak & $\sqsupset L 30.30 .3$ & 1.36 & 2.356 \\
\hline $15-2 D$ & 13 & 2.598 & -892.82 & tegak & \lrcorner $L 30.30 .3$ & 1.36 & 3.533 \\
\hline $15-2 D$ & 14 & 3.464 & -899.52 & tegak & $J L 30.30 .3$ & 1.36 & 4.711 \\
\hline $15-2 D$ & 15 & 4.33 & 0 & tegak & \lrcorner $L 30.30 .3$ & 1.36 & 5.889 \\
\hline $15-2 D$ & 16 & 3.464 & -899.52 & tegak & \lrcorner $L 30.30 .3$ & 1.36 & 4.711 \\
\hline $15-2 D$ & 17 & 2.598 & -892.82 & tegak & \lrcorner $L 30.30 .3$ & 1.36 & 3.533 \\
\hline $15-2 D$ & 18 & 1.732 & -799.52 & tegak & \lrcorner $L 30.30 .3$ & 1.36 & 2.356 \\
\hline $15-2 D$ & 19 & 0.866 & -619.62 & tegak & $J L 30.30 .3$ & 1.36 & 1.178 \\
\hline $15-2 D$ & 20 & 1.73204 & -8870.61 & atas & \lrcorner $L 50.50 .5$ & 3.77 & 6.530 \\
\hline $15-2 D$ & 21 & 1.73204 & -8870.61 & atas & \lrcorner$\llcorner 50.50 .5$ & 3.77 & 6.530 \\
\hline $15-2 D$ & 22 & 1.73204 & -8250.98 & atas & \lrcorner $L 50.50 .5$ & 3.77 & 6.530 \\
\hline $15-2 D$ & 23 & 1.73204 & -7717.95 & atas & \lrcorner $L 50.50 .5$ & 3.77 & 6.530 \\
\hline $15-2 D$ & 24 & 1.73204 & -7271.53 & atas & \lrcorner $L 50.50 .5$ & 3.77 & 6.530 \\
\hline $15-2 D$ & 25 & 1.73204 & -7271.53 & atas & \lrcorner $L 50.50 .5$ & 3.77 & 6.530 \\
\hline $15-2 D$ & 26 & 1.73204 & -7717.95 & atas & $J\llcorner 50.50 .5$ & 3.77 & 6.530 \\
\hline $15-2 D$ & 27 & 1.73204 & -8250.98 & atas & \lrcorner $L 50.50 .5$ & 3.77 & 6.530 \\
\hline $15-2 D$ & 28 & 1.73204 & -8870.61 & atas & \lrcorner$\llcorner 50.50 .5$ & 3.77 & 6.530 \\
\hline $15-2 D$ & 29 & 1.73204 & -8870.61 & atas & \lrcorner $L 50.50 .5$ & 3.77 & 6.530 \\
\hline $15-2 D$ & 30 & 2.29125 & 819.69 & diagonal & $J\llcorner 30.30 .3$ & 1.36 & 3.116 \\
\hline $15-2 D$ & 31 & 2.99993 & 923.21 & diagonal & \lrcorner $L 30.30 .3$ & 1.36 & 4.080 \\
\hline $15-2 D$ & 32 & 3.77482 & 972.94 & diagonal & $J L 30.30 .3$ & 1.36 & 5.134 \\
\hline $15-2 D$ & 33 & 4.58246 & 951.96 & diagonal & $J L 30.30 .3$ & 1.36 & 6.232 \\
\hline $15-2 D$ & 34 & 4.58246 & 951.96 & diagonal & \lrcorner $L 30.30 .3$ & 1.36 & 6.232 \\
\hline $15-2 D$ & 35 & 3.77482 & 972.94 & diagonal & $J L 30.30 .3$ & 1.36 & 5.134 \\
\hline $15-2 D$ & 36 & 2.99993 & 923.21 & diagonal & \lrcorner $L 30.30 .3$ & 1.36 & 4.080 \\
\hline \multirow[t]{3}{*}{$15-2 D$} & 37 & 2.29125 & 819.69 & diagonal & \lrcorner$\llcorner 30.30 .3$ & 1.36 & 3.116 \\
\hline & & & & & & & 182.566 \\
\hline & & & & & Tota & da-kuda & 200.822 \\
\hline
\end{tabular}


Tabel 3. Berat konstruksi 1/2 Kuda-kuda bentang $15 \mathrm{M}-2$ dimensi

\begin{tabular}{|c|c|c|c|c|c|c|c|}
\hline $\begin{array}{c}\text { Bentang } \\
M\end{array}$ & $\begin{array}{c}\text { Frame } \\
\text { Text }\end{array}$ & $\begin{array}{r}\text { Station } \\
\mathrm{m}\end{array}$ & $\begin{array}{r}P \\
\text { Kgf }\end{array}$ & & Profil & $\begin{array}{l}\text { berat } \\
\mathrm{kg} / \mathrm{m}\end{array}$ & $\begin{array}{c}\text { berat } \\
\mathrm{kg}\end{array}$ \\
\hline 15 - $1 / 2$ kuda2 & 1 & 1.5 & 923.24 & bawah & $J\llcorner 30.30 .3$ & 1.36 & 2.040 \\
\hline $15-1 / 2$ kuda2 & 2 & 1.5 & 386.61 & bawah & \lrcorner $\mathrm{L} 30.30 .3$ & 1.36 & 2.040 \\
\hline 15 - $1 / 2$ kuda2 & 3 & 1.5 & -75 & bawah & \lrcorner $\mathrm{L} 30.30 .3$ & 1.36 & 2.040 \\
\hline 15 - $1 / 2$ kuda2 & 4 & 1.5 & -461.62 & bawah & \lrcorner $\mathrm{L} 30.30 .3$ & 1.36 & 2.040 \\
\hline $15-1 / 2$ kuda2 & 5 & 1.5 & -773.23 & bawah & \lrcorner $L 30.30 .3$ & 1.36 & 2.040 \\
\hline $15-1 / 2$ kuda2 & 6 & 0.866 & -619.62 & tegak & \lrcorner $\mathrm{L} 30.30 .3$ & 1.36 & 1.178 \\
\hline $15-1 / 2$ kuda2 & 7 & 1.732 & -799.52 & tegak & \lrcorner $L 30.30 .3$ & 1.36 & 2.356 \\
\hline 15 - $1 / 2$ kuda2 & 8 & 2.598 & -892.82 & tegak & \lrcorner $L 30.30 .3$ & 1.36 & 3.533 \\
\hline 15 - $1 / 2$ kuda2 & 9 & 3.464 & -899.52 & tegak & \lrcorner $L 30.30 .3$ & 1.36 & 4.711 \\
\hline $15-1 / 2$ kuda2 & 10 & & & & & & \\
\hline $15-1 / 2$ kuda2 & 11 & 1.73204 & -1958.9 & Atas & \lrcorner $L 30.30 .3$ & 1.36 & 2.356 \\
\hline $15-1 / 2$ kuda2 & 12 & 1.73204 & -1958.9 & Atas & \lrcorner $\mathrm{L} 30.30 .3$ & 1.36 & 2.356 \\
\hline $15-1 / 2$ kuda2 & 13 & 1.73204 & -1339.26 & Atas & \lrcorner $L 30.30 .3$ & 1.36 & 2.356 \\
\hline 15 - $1 / 2$ kuda2 & 14 & 1.73204 & -806.24 & Atas & \lrcorner $L 30.30 .3$ & 1.36 & 2.356 \\
\hline 15 - $1 / 2$ kuda2 & 15 & 1.73204 & -359.81 & Atas & \lrcorner $L 30.30 .3$ & 1.36 & 2.356 \\
\hline $15-1 / 2$ kuda2 & 16 & 2.29125 & 819.69 & diagonal & \lrcorner $L 30.30 .3$ & 1.36 & 3.116 \\
\hline $15-1 / 2$ kuda2 & 17 & 2.99993 & 923.21 & diagonal & \lrcorner $L 30.30 .3$ & 1.36 & 4.080 \\
\hline 15 - 1/2 kuda2 & 18 & 3.77482 & 972.94 & diagonal & \lrcorner $L 30.30 .3$ & 1.36 & 5.134 \\
\hline \multirow[t]{2}{*}{15 - $1 / 2$ kuda2 } & 19 & 4.58246 & 951.96 & diagonal & \lrcorner $L 30.30 .3$ & 1.36 & 6.232 \\
\hline & & & & & & & 52.317 \\
\hline
\end{tabular}

Tabel 4. Berat konstruksi Kuda-kuda bentang $15 \mathrm{M}-3$ dimensi

\begin{tabular}{|c|c|c|c|c|c|c|c|}
\hline $\begin{array}{c}\text { Bentang } \\
\mathrm{m}\end{array}$ & $\begin{array}{c}\text { Frame } \\
\text { Text } \\
\end{array}$ & $\begin{array}{r}\text { Station } \\
\mathrm{m}\end{array}$ & $\begin{array}{r}\mathbf{P} \\
\mathrm{Kgf}\end{array}$ & & Profil & $\begin{array}{l}\text { berat } \\
\mathrm{kg} / \mathrm{m}\end{array}$ & $\begin{array}{c}\text { berat } \\
\mathrm{kg}\end{array}$ \\
\hline $15-3 D$ & 1 & 1.5 & 4574.62 & bawah & $J[35.35 .4$ & 2.1 & 3.150 \\
\hline $15-3 D$ & 2 & 1.5 & 4038 & bawah & \lrcorner $L_{35.35 .4}$ & 2.1 & 3.150 \\
\hline $15-3 D$ & 3 & 1.5 & 3576.38 & bawah & \lrcorner $\mathrm{L} 35.35 .4$ & 2.1 & 3.150 \\
\hline $15-3 D$ & 4 & 1.5 & 3189.76 & bawah & \lrcorner $L_{35.35 .4}$ & 2.1 & 3.150 \\
\hline $15-3 D$ & 5 & 1.5 & 2878.15 & bawah & \lrcorner $L 35.35 .4$ & 2.1 & 3.150 \\
\hline $15-3 D$ & 6 & 1.5 & 2878.15 & bawah & \lrcorner $L 35.35 .4$ & 2.1 & 3.150 \\
\hline $15-3 D$ & 7 & 1.5 & 3189.76 & bawah & \lrcorner $L 35.35 .4$ & 2.1 & 3.150 \\
\hline $15-3 D$ & 8 & 1.5 & 3576.38 & bawah & \lrcorner $L_{35.35 .4}$ & 2.1 & 3.150 \\
\hline $15-3 D$ & 9 & 1.5 & 4038 & bawah & \lrcorner $L_{35.35 .4}$ & 2.1 & 3.150 \\
\hline $15-3 D$ & 10 & 1.5 & 4574.62 & bawah & \lrcorner $L 35.35 .4$ & 2.1 & 3.150 \\
\hline $15-3 D$ & 11 & 0.866 & -619.62 & tegak & \lrcorner $L_{30.30 .3}$ & 1.36 & 1.178 \\
\hline $15-3 D$ & 12 & 1.732 & -799.52 & tegak & \lrcorner $L 30.30 .3$ & 1.36 & 2.356 \\
\hline $15-3 D$ & 13 & 2.598 & -892.82 & tegak & \lrcorner $L_{30.30 .3}$ & 1.36 & 3.533 \\
\hline $15-3 D$ & 14 & 3.464 & -899.52 & tegak & \lrcorner $L_{30.30 .3}$ & 1.36 & 4.711 \\
\hline $15-3 D$ & 15 & 4.33 & 0 & tegak & \lrcorner $\mathrm{L} 30.30 .3$ & 1.36 & 5.889 \\
\hline $15-3 D$ & 16 & 3.464 & -899.52 & tegak & \lrcorner $L_{30.30 .3}$ & 1.36 & 4.711 \\
\hline $15-3 D$ & 17 & 2.598 & -892.82 & tegak & \lrcorner $L_{30.30 .3}$ & 1.36 & 3.533 \\
\hline $15-3 D$ & 18 & 1.732 & -799.52 & tegak & \lrcorner $L_{30.30 .3}$ & 1.36 & 2.356 \\
\hline $15-3 D$ & 19 & 0.866 & -619.62 & tegak & \lrcorner $\mathrm{L} 30.30 .3$ & 1.36 & 1.178 \\
\hline $15-3 D$ & 20 & 1.73204 & -5282.28 & atas & \lrcorner $L 40.40 .4$ & 2.42 & 4.192 \\
\hline
\end{tabular}




\begin{tabular}{|c|c|c|c|c|c|c|c|}
\hline $\begin{array}{c}\text { Bentang } \\
\mathrm{m}\end{array}$ & $\begin{array}{c}\text { Frame } \\
\text { Text }\end{array}$ & $\begin{array}{r}\text { Station } \\
\mathrm{m}\end{array}$ & $\begin{array}{r}\mathbf{P} \\
\mathrm{Kgf} \\
\end{array}$ & & Profil & $\begin{array}{l}\text { berat } \\
\mathrm{kg} / \mathrm{m}\end{array}$ & $\begin{array}{c}\text { berat } \\
\mathrm{kg}\end{array}$ \\
\hline $15-3 D$ & 21 & 1.73204 & -5282.28 & atas & $J\llcorner 40.40 .4$ & 2.42 & 4.192 \\
\hline $15-3 D$ & 22 & 1.73204 & -4662.64 & atas & \lrcorner $L 40.40 .4$ & 2.42 & 4.192 \\
\hline $15-3 D$ & 23 & 1.73204 & -4129.62 & atas & \lrcorner $\mathrm{L} 40.40 .4$ & 2.42 & 4.192 \\
\hline $15-3 D$ & 24 & 1.73204 & -3683.2 & atas & \lrcorner $L 40.40 .4$ & 2.42 & 4.192 \\
\hline $15-3 D$ & 25 & 1.73204 & -3683.2 & atas & \lrcorner $\mathrm{L} 40.40 .4$ & 2.42 & 4.192 \\
\hline $15-3 D$ & 26 & 1.73204 & -4129.62 & atas & \lrcorner $L 40.40 .4$ & 2.42 & 4.192 \\
\hline $15-3 D$ & 27 & 1.73204 & -4662.64 & atas & \lrcorner$\llcorner 40.40 .4$ & 2.42 & 4.192 \\
\hline $15-3 D$ & 28 & 1.73204 & -5282.28 & atas & \lrcorner $L 40.40 .4$ & 2.42 & 4.192 \\
\hline $15-3 D$ & 29 & 1.73204 & -5282.28 & atas & \lrcorner $\mathrm{L} 40.40 .4$ & 2.42 & 4.192 \\
\hline $15-3 D$ & 30 & 2.29125 & 819.69 & diagonal & \lrcorner $L 30.30 .3$ & 1.36 & 3.116 \\
\hline $15-3 D$ & 31 & 2.99993 & 923.21 & diagonal & \lrcorner $L 30.30 .3$ & 1.36 & 4.080 \\
\hline $15-3 D$ & 32 & 3.77482 & 972.94 & diagonal & \lrcorner $L_{30.30 .3}$ & 1.36 & 5.134 \\
\hline $15-3 D$ & 33 & 4.58246 & 951.96 & diagonal & \lrcorner $L 30.30 .3$ & 1.36 & 6.232 \\
\hline $15-3 D$ & 34 & 4.58246 & 951.96 & diagonal & \lrcorner $L 30.30 .3$ & 1.36 & 6.232 \\
\hline $15-3 D$ & 35 & 3.77482 & 972.94 & diagonal & \lrcorner $L_{30.30 .3}$ & 1.36 & 5.134 \\
\hline $15-3 D$ & 36 & 2.99993 & 923.21 & diagonal & \lrcorner $L 30.30 .3$ & 1.36 & 4.080 \\
\hline $15-3 D$ & 37 & 2.29125 & 819.69 & diagonal & \lrcorner $L 30.30 .3$ & 1.36 & 3.116 \\
\hline $15-3 D$ & 38 & 1.5 & 4574.62 & bawah & \lrcorner $L 35.35 .4$ & 2.1 & 3.150 \\
\hline $15-3 D$ & 39 & 1.5 & 4038 & bawah & \lrcorner $L_{35.35 .4}$ & 2.1 & 3.150 \\
\hline $15-3 D$ & 40 & 1.5 & 3576.38 & bawah & \lrcorner $L_{35.35 .4}$ & 2.1 & 3.150 \\
\hline $15-3 D$ & 41 & 1.5 & 3189.76 & bawah & \lrcorner$\llcorner 35.35 .4$ & 2.1 & 3.150 \\
\hline $15-3 D$ & 42 & 1.5 & 2878.15 & bawah & \lrcorner $L 35.35 .4$ & 2.1 & 3.150 \\
\hline $15-3 D$ & 43 & 0.866 & -619.62 & tegak & \lrcorner $L 30.30 .3$ & 1.36 & 1.178 \\
\hline $15-3 D$ & 44 & 1.732 & -799.52 & tegak & \lrcorner $L_{30.30 .3}$ & 1.36 & 2.356 \\
\hline $15-3 D$ & 45 & 2.598 & -892.82 & tegak & \lrcorner $L 30.30 .3$ & 1.36 & 3.533 \\
\hline $15-3 D$ & 46 & 3.464 & -899.52 & tegak & \lrcorner $L_{30.30 .3}$ & 1.36 & 4.711 \\
\hline $15-3 D$ & 47 & 1.73204 & -5282.28 & atas & \lrcorner $L 40.40 .4$ & 2.42 & 4.192 \\
\hline $15-3 D$ & 48 & 1.73204 & -5282.28 & atas & \lrcorner $L 40.40 .4$ & 2.42 & 4.192 \\
\hline $15-3 D$ & 49 & 1.73204 & -4662.64 & atas & \lrcorner $L 40.40 .4$ & 2.42 & 4.192 \\
\hline $15-3 D$ & 50 & 1.73204 & -4129.62 & atas & \lrcorner$\llcorner$ L 40.40 .4 & 2.42 & 4.192 \\
\hline $15-3 D$ & 51 & 1.73204 & -3683.2 & atas & \lrcorner$\llcorner 40.40 .4$ & 2.42 & 4.192 \\
\hline $15-3 D$ & 52 & 2.29125 & 819.69 & diagonal & \lrcorner $L_{30.30 .3}$ & 1.36 & 3.116 \\
\hline $15-3 D$ & 53 & 2.99993 & 923.21 & diagonal & \lrcorner $L 30.30 .3$ & 1.36 & 4.080 \\
\hline $15-3 D$ & 54 & 3.77482 & 972.94 & diagonal & \lrcorner $L_{30.30 .3}$ & 1.36 & 5.134 \\
\hline $15-3 D$ & 55 & 4.58246 & 951.96 & diagonal & \lrcorner $L_{30.30 .3}$ & 1.36 & 6.232 \\
\hline $15-3 D$ & 56 & 1.5 & 2878.15 & bawah & \lrcorner $L 35.35 .4$ & 2.1 & 3.150 \\
\hline $15-3 D$ & 57 & 1.5 & 3189.76 & bawah & \lrcorner $L 35.35 .4$ & 2.1 & 3.150 \\
\hline $15-3 D$ & 58 & 1.5 & 3576.38 & bawah & \lrcorner $L_{35.35 .4}$ & 2.1 & 3.150 \\
\hline $15-3 D$ & 59 & 1.5 & 4038 & bawah & \lrcorner $L_{35.35 .4}$ & 2.1 & 3.150 \\
\hline $15-3 D$ & 60 & 1.5 & 4574.62 & bawah & \lrcorner $L_{35.35 .4}$ & 2.1 & 3.150 \\
\hline $15-3 D$ & 61 & 3.464 & -899.52 & tegak & \lrcorner $L 30.30 .3$ & 1.36 & 4.711 \\
\hline $15-3 D$ & 62 & 2.598 & -892.82 & tegak & \lrcorner $L_{30.30 .3}$ & 1.36 & 3.533 \\
\hline $15-3 D$ & 63 & 1.732 & -799.52 & tegak & \lrcorner $L_{30.30 .3}$ & 1.36 & 2.356 \\
\hline $15-3 D$ & 64 & 0.866 & -619.62 & tegak & \lrcorner $L_{30.30 .3}$ & 1.36 & 1.178 \\
\hline $15-3 D$ & 65 & 1.73204 & -3683.2 & atas & \lrcorner $\mathrm{L} 40.40 .4$ & 2.42 & 4.192 \\
\hline $15-3 D$ & 66 & 1.73204 & -4129.62 & atas & \lrcorner $L 40.40 .4$ & 2.42 & 4.192 \\
\hline $15-3 D$ & 67 & 1.73204 & -4662.64 & atas & \lrcorner$\llcorner 40.40 .4$ & 2.42 & 4.192 \\
\hline $15-3 D$ & 68 & 1.73204 & -5282.28 & atas & \lrcorner $\mathrm{L} 40.40 .4$ & 2.42 & 4.192 \\
\hline
\end{tabular}




\begin{tabular}{|c|c|c|c|c|c|c|c|}
\hline $\begin{array}{c}\text { Bentang } \\
\mathrm{m}\end{array}$ & $\begin{array}{c}\text { Frame } \\
\text { Text }\end{array}$ & $\begin{array}{r}\text { Station } \\
\mathrm{m}\end{array}$ & $\begin{array}{r}P \\
\text { Kgf }\end{array}$ & & Profil & $\begin{array}{l}\text { berat } \\
\mathrm{kg} / \mathrm{m}\end{array}$ & $\begin{array}{c}\text { berat } \\
\mathrm{kg}\end{array}$ \\
\hline $15-3 D$ & 69 & 1.73204 & -5282.28 & atas & \lrcorner $L_{40.40 .4}$ & 2.42 & 4.192 \\
\hline $15-3 D$ & 70 & 4.58246 & 951.96 & diagonal & \lrcorner $L_{30.30 .3}$ & 1.36 & 6.232 \\
\hline $15-3 D$ & 71 & 3.77482 & 972.94 & diagonal & \lrcorner $L 30.30 .3$ & 1.36 & 5.134 \\
\hline $15-3 D$ & 72 & 2.99993 & 923.21 & diagonal & \lrcorner $L 30.30 .3$ & 1.36 & 4.080 \\
\hline \multirow[t]{2}{*}{$15-3 D$} & 73 & 2.29125 & 819.69 & diagonal & \lrcorner $L_{30.30 .3}$ & 1.36 & 3.116 \\
\hline & & & & & & & 274.078 \\
\hline
\end{tabular}

Pada kuda-kuda dengan bentang $15 \mathrm{~m}$, diperoleh, berat kuda-kuda KK1 (arah X) adalah 401,645 kg, berat $1 / 2$ kuda-kuda (arah Y - 2 buah) adalah 230,196 kg. Sehingga dengan perhitungan 2 dimensi berat kuda-kuda arah $X$ dan $Y$ adalah $631,841 \mathrm{~kg}$. Dengan perhitungan 3 dimensi, berat kuda-kuda arah $\mathrm{X}$ dan $\mathrm{Y}$ adalah $602,971 \mathrm{~kg}$. Maka berat konstruksi kuda-kuda dengan perhitungan 3 dimensi adalah 95,43\% dari berat konstruksi kuda-kuda dengan perhitungan 2 dimensi.

Berat kuda-kuda untuk tiap bentang dapat dilihat pada tabel berikut :

Tabel 5. Berat Kuda-kuda

\begin{tabular}{|c|c|c|c|c|c|}
\hline \multirow{2}{*}{$\begin{array}{c}\text { Bentang } \\
(\mathrm{m})\end{array}$} & \multicolumn{4}{|c|}{ Kuda-kuda } & Perbandingan \\
\cline { 2 - 5 } & KK1 & $1 / 2$ kuda2 & 2 D & 3 D & 3 D / 2 D \\
\hline 12 & 262.632 & 162.706 & 425.338 & 400.402 & $94.14 \%$ \\
\hline 15 & 401.645 & 230.196 & 631.841 & 602.971 & $95.43 \%$ \\
\hline 18 & 634.160 & 413.247 & $1,047.407$ & 992.901 & $94.80 \%$ \\
\hline 21 & 886.993 & 610.873 & $1,497.865$ & $1,381.439$ & $92.23 \%$ \\
\hline 24 & $1,362.647$ & 78.399 & $1,241.047$ & $1,943.826$ & $86.74 \%$ \\
\hline
\end{tabular}

Dari tabel tabel di atas, terlihat bahwa kuda-kuda yang dihitung menggunakan SAP 3 dimensi menghasilkan berat konstruksi yang lebih ringan dibandingkan dengan perhitungan SAP2 dimensi.

\section{KESIMPULAN}

1. Perhitungan gaya batang pada konstruksi rangka kuda-kuda dengan menggunakan metode SAP 3 dimensi memerlukan data yang lebih komplek dibandingkan perhitungan metode 2 dimensi.

2. Pada kuda-kuda dengan bentang $12 \mathrm{~m}$, diperoleh, berat kuda-kuda KK1 ( $\operatorname{arah} \mathrm{X}$ ) adalah 262, $632 \mathrm{~kg}$, berat $1 / 2$ kuda-kuda (arah $Y-2$ buah) adalah 162,706 kg. Sehingga dengan 
perhitungan 2 dimensi berat kuda-kuda arah $X$ dan $Y$ adalah 425,338 kg. Dengan perhitungan 3 dimensi, berat kuda-kuda arah $X$ dan $Y$ adalah 400,402 kg. Maka berat konstruksi kudakuda dengan perhitungan 3 dimensi adalah 94,14\% dari berat konstruksi kuda-kuda dengan perhitungan 2 dimensi.

3. Perbandingan berat konstruksi kuda-kuda yang dihitung dengan 3 dimensi dibandingkan dengan 2 dimensi, untuk bentang $15 \mathrm{~m}$ adalah 95,43\%, bentang bentang $18 \mathrm{~m}$ adalah $94,80 \%$, bentang $21 \mathrm{~m}$ adalah $92,23 \%$ dan bentang $24 \mathrm{~m}$ adalah $86,74 \%$.

\section{DAFTAR PUSTAKA}

Amon, Rene dan K, Bruce dan Mazumder Atanu. , 1998a, Perencanaan Konstruksi Baja Untuk Insinyur dan Arsitek 1. PT. Pradnya Paramita, Jakarta

Amon, Rene dan K, Bruce dan Mazumder Atanu. , 1998b, Perencanaan Konstruksi Baja Untuk Insinyur dan Arsitek 2. PT. Pradnya Paramita, Jakarta

AP, Pius dan Y, Trisno. ,1994, Kamus Kecil Bahasa Indonesia. Arkola, Surabaya.

Arikunti, Suharsimi. ,1993, Manajemen Penelitian. PT. Rineka Cipta, Jakarta

Frick, Heinz. , 2004, Mekanika Teknik 1. Kanisius Yogyakarta.

Gunawan, Rudy. ,1991a, Pengantar IImu Bangunan. Kanisius, Yogyakarta.

Gunawan, Rudy. ,1991b, Tabel Profil Konstruksi Baja, Yogyakarta.

Puspantoro, Benny. ,1995, Konstruksi Bangunan Gedung. Andi Offset, Yogyakarta.

Sudjana. ,1996, Metoda Statika Edisi ke-6. Tarsito, Bandung.

Supriadi, IK, 1996a, IImu Bahan Bangunan Gedung Seri A, Armico. Bandung.

Supriadi, IK., 1996b, IImu Bahan Bangunan Gedung Seri B , Armico, Bandung.

Sorowiyono, TW, Tutu. ,1991, Dasar-dasar Perencanaan Rumah Tinggal., Pustaka Sinar Harapan, Jakarta.

T, Gunawan dan S, Margaret. , 2003, Konstruksi Baja II. Delta Teknik Group, Jakarta.

Frick Heinz, Setiawan Pujo L. ,2001, Ilmu Konstruksi Struktur Bangunan, Kanisius, Yogyakarta 
ISSN: $1907-4360$

Tim Penelitian dan Pengembangan Wahana Komputer, 2003, Analisis dan Perhitungan Struktur dengan SAP 2000, Salemba Infotek, Jakarta

Tim Penyusun Kamus Pusat Bahasa, 2001, Kamus Besar Bahasa Indonesia (Edisi Ketiga), Balai Pustaka, Jakarta

SAP 2000 , 1995, Integrated Fineted Element Analysis and Design of Structure Getting Started, Computer and Structure Inc. Berkeley, California USA 